\title{
A.D. HOPE'S ESSAYS ON RUSSIAN LITERATURE
}

\author{
DAVID N. WELLS \\ Curtin University of Technology
}

In the fifth of his "Western Elegies," written towards the end of his career, the pre-eminent Australian poet A. D. Hope notes the importance for him as a person and as a writer of his exposure to languages and cultures other than English. For the speaker of more than one language, he writes, aware that neither thought nor feeling is properly translatable,

his soul grows still and attentive,

Aware, beyond any speech, of a metaphysics of meaning

Which teaches that not mere words but the heart is what must be translated. ${ }^{1}$

Hope was an avid learner of languages throughout his life, from Latin to Arabic and Japanese, and, as Kevin Hart has noted, "had access to a far wider range of poetries and poetics than any other Australian poet." 2 His poetry and criticism, accordingly, engage closely with an enormous wealth of material from the European tradition and beyond, focussing particularly on ancient Greece and Rome, on the modern "tongues of Italy, France and Iberia," and the "tongues of the Goths and the Germans, the Norse and the Anglo-Saxons," in which Hope specialised when at Oxford. Hope describes Russian as the "Last of the tongues of men into which my soul found translation" (Hope, Orpheus, 13), and from the mid1960s onwards it is true to say that Russian literature occupied as important a place in his thinking and writing as any of the numerous other non-English cultural traditions on which he drew. Several of Hope's late projects centred on this interest in Russian 
literature. The most ambitious of these was his attempt to compile a volume of critical essays on Russian themes. Although this project was never completed, it is clear that in his examination of the Russian authors he chose to discuss, Hope was striving to create a statement about the nature of literature and the role of the poet in society which was also of direct relevance to his own practice as a writer. This article draws on the papers, correspondence and notebooks in Hope's archive at the National Library of Australia, as well as on Hope's published writing on Russian themes, to explore the full range of Hope's engagement with Russian literature and to demonstrate its centrality to his thinking in his last three decades as a poet.

\section{I}

Hope had met Russians while he was studying at Oxford (192831): most notably the Russian language was prominent at Lacock Abbey, the country house in Wiltshire where Hope spent much of his free time when in England. Among Lacock's other regular guests was a certain Mrs Perrin, an exiled Russian aristocrat "who filled the house with Russian and an air of excitement which she carries with her everywhere." 3 Hope's hostess at Lacock, Maud Talbot, was well versed in European languages and literatures, including Russian, and she and Mrs Perrin were "continually skirmishing in the Russian tongue."4 In his letters from Oxford, Hope also notes more varied intellectual encounters with Russian culture: the viewing of the film Rasputin, the Holy Devil, ${ }^{5}$ and a reading of Chekhov's play The Cherry Orchard as part of the activities of a play-reading society with which he was involved. ${ }^{6}$ Perhaps inspired by these English experiences, on his return to Australia in 1931 Hope began to teach himself Russian, using a grammar together with the readers written by Lev Tolstoi in the 1870s for the peasant schools on his estate at Iasnaia Poliana. Hope took Russian lessons in Sydney and appears to have developed quite strong links with members of the Russian community there (Hope, Chance Encounters 76-7). Certainly he was still corresponding with his first teacher, Ursula Schwallbach, and other Russian-speaking acquaintances from this period, into the 1980s.

Since a large part of Hope's papers was destroyed by a fire at the Australian National University in 1953 it is hard to trace his involvement with Russian themes during the two decades following his return to Australia. Occasional Russian allusions in the available documents, such as signing a letter to his future wife in 1939 as "Aleksei Persikovich Gop" ('Gop' being a form of the name 'Hope' 
as it would be transcribed into Russian script), suggest that a certain Russian sensibility had pervaded his everyday consciousness, ${ }^{7}$ and indeed in later writings Hope not infrequently inserts Russian words or phrases into comments which themselves have no bearing on Russian themes. For example, a 1957 notebook entry on the relationship between drinking and sex is headed (in Cyrillic letters) "Naoborot!" [On the Contrary]. ${ }^{8}$ A 1970 entry in which Hope reflects on the costs of fame and consoles himself with the thought that he has scattered interviews around the world like animal droppings is entitled "Coprologia or Populiarnost" [popularity]. ${ }^{\text {" }}$

The question can reasonably be asked: how good was Hope's Russian? Probably, he gained a respectable speaking knowledge in the 1930s, though by 1992 in Chance Encounters he notes that through lack of practice, as with his numerous other languages, he is no longer able to sustain even the simplest conversation (Hope, Chance Encounters, 79). Yet for the most part it was a reading knowledge of foreign languages that Hope held to be important to his vocation as a poet. In The New Cratylus he describes the method he applied to acquiring new languages: to learn the rudiments of grammar, then to immerse himself in poetry until he arrived at the "flash point" needed for "the essential feel" of the language. ${ }^{10}$ This method is perhaps calculated, as Hope admitted, to encourage a "feeling of language abstracted from its everyday, practical association," but he does seem to have learned to read Russian with considerable facility, and continued to do so until late in life. This is suggested by the often extensive Russian quotations copied into his notebooks with annotations in English, the notes he took from Russian sources, the copies of articles in Russian stored with his other papers, and the letters in Russian from correspondents such as Nina Christesen. And although Hope not infrequently found it necessary to gloss Russian texts with English translations for words he did not know, and is occasionally guilty of misreading-his acknowledged creative misreading of the title of Anna Akhmatova's cycle "Tainy remesla" [Secrets of the Craft] as "Tainye remesla" [Secret Crafts] is a case in point ${ }^{11}$ - Hope's Russian was most certainly more than adequate to its essential task: absorbing the rhythms and themes of a foreign literature into his own poetic sensibility. That he had fully internalised these rhythms is suggested by a dream he recounts in a notebook entry for 1973. Here he is writing an ode, in Russian, on the death of Pushkin. Two lines (of uncertain metre) remained imperfectly in his memory on waking: "Budet Pushkin, budet slava ego / Do sroka ... ykh vekov" [Pushkin will live, his fame will live / Till the end of ... ages). ${ }^{12}$ 
Hope's most explicit and active engagement with Russian literature began in the late 1960s, following his retirement from the Australian National University, and his release from his administrative and teaching duties there. Hope had known Nina Christesen, the founder of Russian studies in Australia and lecturer at Melbourne University, since at least 1946, ${ }^{13}$ and in 1967 he became a founding member of the advisory board of the new journal Melbourne Slavonic Studies, which Christesen edited. Hope was to publish several critical articles on Russian topics in this journal over the next few years. He gave regular guest lectures on Tolstoi and Dostoevsky to students in the Melbourne English Department, and also addressed Christesen's students on Russian poetry (Armstrong 92). His papers contain drafts and notes for several of these lectures, which covered such topics as the work of Akhmatova, Mandelstam, Pasternak, Mayakovsky and Voznesensky; the flourishing of poetry at the turn of the twentieth century in Russia and the subsequent disillusionment of writers with the Bolshevik revolution; and the literature of resistance in subsequent years. ${ }^{14}$

Hope's early reading in Russian literature appears not to have gone beyond the usual nineteenth-century classics. In a notebook entry of 1971, for example, he recalls learning by heart several of Ivan Krylov's fables when he was studying Russian in the 1930s. ${ }^{15}$ The earliest references to Russian literature in Hope's papers are to Pushkin and Tolstoi, whose names recur regularly in different contexts over several decades. Other names that appear include Dostoevsky, Tiutchev, Baratynsky and Chekhov. Hope's unrealised project for a book of critical essays on the poetic achievement of women writers, The Distaff and the Lyre, led him also to the peasant poet Irina Andreevna Fedosova (1831-99) and to Karolina Pavlova (1807-93), ${ }^{16}$ as well as to the much better known Anna Akhmatova and Marina Tsvetaeva.

On the evidence of the notebooks and other papers, from the early 1960s onwards Hope also began to take an interest in twentieth-century writers, apparently taking as his starting-point Boris Pasternak's Doktor Zbivago, first published in Russian in 1957, and in English translation the following year. Although, generally speaking, politics is almost entirely absent as an overt theme in Hope's writing, ${ }^{17}$ he made an exception in considering the role of the poet in the Soviet Union. As the Russian version of Doktor Zhivago was published in Italy in defiance of the Soviet censorship, Pasternak came under severe attack and was expelled from the Union of Soviet Writers at the instigation of its then General 
Secretary Aleksei Surkov. Hope would naturally have followed the developments surrounding his enforced refusal of the Nobel Prize for literature in 1958 with considerable interest, and in 1972 recalls with some disdain the "hypocritical" remarks made on the subject by Surkov, whom Hope met at the home of Manning Clark in 1962.18 From Pasternak, Hope's interests seem to have spread outwards to include Mayakovsky and other Futurists, to whom he may have been introduced through his reading of Pasternak's autobiographical Okhrannaia gramota [Safe Conduct], and later to younger dissident or semi-dissident writers of the 1960s, notably Abram Tertz (Andrei Siniavsky), Aleksandr Solzhenitsyn and Andrei Voznesenskii. The first two of these were notable victims of Soviet policy towards the arts in the 1960s, while the third, whose career and writing Hope followed particularly closely, was an "official" writer who, while subject to criticism, nevertheless succeeded in achieving a high degree of independence within the Soviet literary establishment. It may have been as writers broadly seen as anti-establishment, and thus associated with the dissident movement, that Hope first encountered Anna Akhmatova and later Osip Mandelstam, to both of whom he devoted a good deal of attention during the 1970s, investigating the broad cultural context of the 1910s in which they first developed as poets (the Russian Silver Age) as well as their later fates and poetic output.

\section{II}

During the 1970s, Hope was also involved in several projects focussing on translations of Russian poetry. As well as working on his own translations from Mandelstam and particularly Akhmatova, he was associated closely with similar endeavours by his friends the poets David Campbell and Rosemary Dobson. In 1970, Hope records a meeting with American poets in New York at which they read their own versions of works by Voznesensky, in many cases prepared from literal translations made by other people. This seems to have been Hope's first encounter with the translation method in which a poet who does not know the source language works in collaboration with a speaker of the language who is not necessarily a poet. Hope notes that in his opinion the results of this sort of collaboration had been mediocre: "Without a fairly good knowledge of the original in its own language, the poet working through a middleman seems to me like a blind man trying to translate the Last Judgement of Michelangelo into music from the description of an unmusical painter."19 
A few years later, however, Hope had clearly modified his view somewhat, and in his foreword to the versions of Akhmatova and Mandelstam published by Campbell and Dobson as Moscow Trefoil in 1975, acknowledges that the combination of poet and native speaker can produce a genuinely creative solution after all. Hope has nothing but praise for the "literal" versions provided by Natalie Staples for this exercise, suggesting that their merit resides both in their literalness and their incompleteness: "Natalie Staples has, as it were, re-dissolved the original back into a stage at which its 'character' or 'tone' is already there, but its elements are still in a fluid and manageable state for another poet to work on it and continue and direct the process of crystallisation." 20 The role of Campbell and Dobson, Hope notes, was not so much to act as "subordinate introducers" of the foreign poets, as to create independent poems treating similar themes "in something the same way that Pope's Epistle to Augustus is based on Horace's Epistle to Augustus," "not so much to sink the translator's identity and spirit in that of the poem and the poet translated as to present the one interpenetrating the other in a new entelechy representing both, but also, in a sense, transcending both" (Hope, "Foreword" vii).

As Moscow Trefoil includes Natalie Staples' literal renditions alongside the versions by Campbell and Dobson for each of the poems selected, the interrelations among the three are also a source of productive aesthetic resonance. The experiment in poetic recreation was continued by Dobson and Campbell, in collaboration this time with Olga Hassanoff and Robert Dessaix, in the selection of translations of Russian poems published as Seven Russian Poets in 1979. ${ }^{21}$

On several occasions Hope expounded his view of the translator's task as interpreter working with the medium of an autonomous language to allow the original to speak in a new context to a new audience. This idea is most notably expressed in a paper on Akhmatova given at a seminar on translation from Russian at the Australian National University in 1977 and in related publications. ${ }^{22}$ His view is also very clearly reflected in his own practice as a translator, in which translation as such and imitation are closely intertwined. Hope's principal achievement in this area was the poetic cycle "Homage to Anna Akhmatova," where original poetry and translation are strikingly combined to produce one of Hope's most powerful statements on the nature of artistic creativity, in which he both links Akhmatova and her role as a poet for her generation with the classical mythology of rebirth and 
implies that his own poetry is a continuation of Akhmatova as well as of the classical tradition itself. ${ }^{23}$

\section{III}

It was also during the 1970s and 1980s that Hope first planned to produce a volume of critical essays on Russian themes. He evidently at one stage intended to include his Russian articles in his collection of essays The Pack of Autolycus, which was in the event published without them in 1978.24 Hope's Russian project, however, clearly outgrew the scope of the more general collection, and there exist among his papers several outlines for a volume specifically on Russian literature. That Hope was slightly diffident about this project in view of his lack of a formal academic background in the area is suggested by his correspondence with Nina Christesen and the Akhmatova specialist Amanda Haight. Both approved the plan, Haight commenting that it was "a very good idea and not at all pretentious." 25 Hope worked on his Russian volume for over a decade and was still hoping to complete it in the late 1980s, noting on one outline that it was "planned to come out in 1988 if I can find a publisher."26

What seems to be the earliest version of the proposed book (ca. 1977?) took the first part of its title from one of Hope's articles on Mandelstam: "The Swallow and the Bee and Other Essays on Russian Literature." It comprised the following chapters:

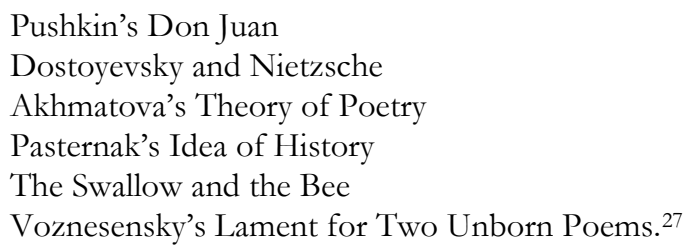

All the essays, apart from the one on "Pasternak's Idea of History," had already been published, at least in preliminary form.

Other, and apparently later, outlines among Hope's papers show that the conception of the volume was gradually expanding in his mind. One file entitled "Sadko and Other Essays on Russian Writers" contains a table of contents beginning with an essay on the folk poem Sadko:

$$
\begin{aligned}
& \text { Sadko } \\
& \text { Pushkin's Don Juan }
\end{aligned}
$$


In Defence of Nataliya Goncharova

Dostoyevsky and Nietzsche

Secrets of the Craft

The Swallow and the Bee

Voznesensky's "Lament for Two Unborn Poems"

Pasternak and History

The Free and the Unfree (Man in 20C Novel revised)

Of these, "Sadko," "In Defence of Nataliya Goncharova" and "Pasternak and History" are marked as unwritten in Hope's notes. ${ }^{28}$

A third, untitled, table of contents is more extensive again:

Preface

Sadko and Tsar Saltan

Pushkin's

Don Juan

Tsar Nikita

The Captain's Daughter

A Case for the Defence

Dostoyevsky and Nietzsche

Tolstoy's Anna Karenina

Alexander Blok

Akhmatova and the Muse

Mandelstam The Blind Swallow

The Swallow and the Bee

Pasternak Causality in Dr Zhivago

Last Poems

Tsvetaeva

Voznesensky Essay on [general essay]

Lament for 2 Unborn Poems

Solzhenitsyn

Safe Conduct ${ }^{29}$

Other ideas for essays noted in Hope's papers suggest he was also thinking of a piece on Mikhail Zoshchenko's expulsion from the Union of Writers in 1946, an article on Krylov and La Fontaine, a piece on Nabokov, and two further articles on Tolstoi: one on the philosophical background of $W$ ar and Peace, the other on "The Kreuzer Sonata." The (apparently unwritten) preface to the proposed volume was to include an acknowledgement of what Hope modestly describes at this stage as his "small acquaintance with Russian," an account of how he came to learn the language and to know members of the Russian community in Australia, and recognition of his particular debt to Nina Christesen..$^{30}$ 
IV

It cannot of course be known with any certainty what the final form of Hope's book of essays on Russian literature would have been, and not all of the ideas recorded in his papers and notebooks appear to have matured into systematic form. It is, however, possible to gain a general idea of the proposed book's main themes. First of all, Hope clearly intended to locate Russian literature firmly within the European tradition, and thus within the cultural context in which he himself operated as a writer. This concern is perhaps most strongly apparent in Hope's writing on Mandelstam, where one of his starting-points is the latter's theory that Russia is the natural heir of ancient Greek culture, of which it comprises an organic continuation and extension. In this context, Hope discusses Mandelstam's use of classical motifs in his poetry of the 1920s at some length, showing how in writing about ancient Greece, Mandelstam is also writing about contemporary Russia. ${ }^{31}$ It is also a major theme in Hope's published articles on Akhmatova, in which an important focus is her treatment of the figure of the Muse. ${ }^{32}$ It is worth noting in this context that in the essay "Poems in the Making," included in The New Cratylus, a discussion of Akhmatova's cycle "Secrets of the Craft" is placed at the centre of a much broader examination of poetic inspiration taking in Plato, Nietzsche, Wordsworth, Yeats and Rimbaud as well as Akhmatova herself. Elsewhere Hope uses Russian examples to illustrate quite general literary points, as, for example, in his notes for an essay on Sadko, which exercise he sees as "Nothing erudite-just the pleasure and reflection on the pleasure of discovering this marvellous tale in all its freshness and colour." 33

Hope affirms the importance of Russian literature on many other occasions, even when it is not a central focus of his argument. His published article on Nietzsche and Dostoevskii, for example, highlights parallels in the thinking of the two writers and offers a partial Nietzschean reading of Dostoevskii's novels. ${ }^{34}$ In discussing the poetry of Voznesensky - where Hope's concern is chiefly with its political context-he makes comparisons with Lorca, Cervantes and Dante. ${ }^{35}$ In his article on Pushkin's "little tragedy" Kamennyi gost' [The Stone Guest], Hope is at pains to show the Russian work in the light of its models in Tirso de Molina, Moliere, Mozart and elsewhere. ${ }^{36}$ In an unpublished article on Pushkin's novel Kapitanskaia dochka [The Captain's Daughter], Hope contrasts the Russian work with contemporary writing in France and England in its "conscious use of fiction to reveal to Russian readers the nature of their own country," and indeed draws 
a parallel in this respect with the American, Canadian and Australian novel. ${ }^{37}$

Secondly, as in The New Cratylus, Hope is interested in the origins of poetry and the nature of creative inspiration. Again, this is a central concern of his writing on Mandelstam and Akhmatova. As I have noted elsewhere, Hope identified strongly with the poetics of the Russian Acmeist movement, of which Akhmatova and Mandelstam were the most prominent representatives, and in his Mandelstam essays pays a great deal of attention to isolating the compositional principles of his poetry, specifically the interweaving of multiple layers of intertextual, autobiographical and private references which go to make up any individual poem (Wells). In writing about Akhmatova, Hope also focuses on the sensitivity to language required of an effective poet and on the Acmeist "semantic" tradition of words as "something living, internal to the poet's own mind and heart concerned more especially with the poet's sense of being chosen, or supplicated, to be the voice of objects, persons or events of the world around" (Hope, "Anna Akhmatova's Secrets of the Craft' 73). Hope is concerned too with the unconscious process which brings these forces together in the mind of the poet, and in a trope reminiscent of his own poem "On the Night Shift" (Hope, Orpheus 17-21), reads Akhmatova's cycle "Secrets of the Craft" as an enumeration of the different figures he sees as essential to his conception of poetry as team-work: the poetcraftsman, the reader, the Muse. Hope's notebooks contain numerous comments on the process of the composition of verse as experienced by Mandelstam, Akhmatova and Pasternak, highlighting the mystery as well as the craftsmanship involved.

Hope's reflections on the nature of the poetic word also led him to contrast Pasternak's early and late poetic styles. He finds in the earlier (Futurist-inspired) works "often an effect of rather decadent 'whining,' a quaintness in the vision instead of a revelation," whereas the verse of Pasternak's late period, including the poems of Doktor Zhivago, Hope describes in terms of Acmeist clarity. ${ }^{38}$ Hope's concern with the language of poetry together with his practical experience of translation informed several essays and reviews in which he considered the rendering of Russian verse into English. In writing about Akhmatova, for example, he relates the translation process to an "original process of composition in which the translator does not try to manipulate his material consciously, but to let the world and the language of the original poem take over and speak through him" (Hope, "Anna Akhmatova: The Secrets of the Craft" 8). In the light of this relatively liberal view of translation 
it is not surprising that elsewhere Hope takes issue with Vladimir Nabokov's principle that translation should be a "literal" rendition of the original. ${ }^{39}$

The biographical impetus behind a work of art is also taken up in Hope's essay on Pushkin's Kamennyi gost', where the distinctiveness of the work is tentatively ascribed to an identification in Pushkin's mind between himself and the character of Don Juan. Hope's interest in Pushkin's amorous biography is perhaps not surprising given his own celebrated affection for the opposite sex. The same preoccupation forms the basis of the poem "Love and Poetry," centred on the figure of Calypso Polychroni, who was supposedly not only Pushkin's mistress, but before him Byron's. Polychroni not only metonymically represents the continuation of the literary tradition from the older poet to the younger, but because of her Greek ancestry also suggests a further cultural link back to the times of Homer (Hope, Orpheus 29). Hope also spent some energy on investigating the life of Pushkin's wife, Natalia Nikolaevna Goncharova, and her relationship with her admirer Georges d'Anthès, who was Pushkin's opponent in his last, fatal duel. A draft essay, "Natalia Nikolaevna: a Case for the Defence," seeks to vindicate Goncharova from the charge that she was unfaithful to Pushkin, and portrays her as a poorly educated young woman, out of her depth in a world of heightened emotion and court intrigue. ${ }^{40}$ Hope's interest in this theme is reflected in his 1967 poem "Having left Pushkin in the snow," which highlights the irony of d'Anthès' later career as president of the Paris Gaslight Co.: he describes the French capital as "la ville lumière, / Lit by the man who quenched the morning star." 41

The third major theme in Hope's writing on Russian literature relates to the ethical imperative for a writer to speak out in defence of freedom of expression. This aspect of the writer's role in society is largely absent from Hope's published articles on Akhmatova and Mandelstam, although the connection between preserving the cultural tradition and maintaining moral values in the face of political oppression is made in his adaptations and translations of their poetry. In the poem "Letter to Amanda," for example, Akhmatova is compared to the classical sibyl in her ability to record and interpret the fate of the Russian people. ${ }^{42}$ Hope's notebooks and drafts demonstrate a more explicit awareness of the persecution of numerous writers in the Soviet Union, including also Pasternak, Zoshchenko and Solzhenitsyn, but his most direct statements on this topic appear in two published articles. 
In one of these, "Safe Conduct," so named from an early autobiographical sketch by Pasternak, Hope outlines the careers of four major Russian poets of the first generation to come to maturity in the Soviet Union: Akhmatova, Mandelstam, Pasternak and Tsvetaeva. ${ }^{43}$ Hope looks at each of these in turn against the background of arbitrary persecution that characterised the time in which they lived. He suggests that in each case their actions could have been expected to bring a greater penalty than they actually did. Pasternak's openly independent stance, for example, did not produce major consequences for Pasternak himself even though friends such as Olga Ivinskaia were given prison sentences because of their connection to him. The sentence of exile given to Mandelstam in 1931 for his "Stalin Ode" was much less than could have been expected. By way of possible explanation Hope speculates, with some plausibility, that the poets were being protected at the highest levels by Stalin himself, and, referring to Alexander the Great's protection of the poet Pindar, implies that great poets are always surrounded in some way by a protective aura.

Hope's published essay on Voznesensky looks closely at the actual mechanisms of literary dissent within a single poem (Hope, "Voznesensky's 'Lament" 38-57). Voznesnensky's "Plach po dvum nerozhdennym poemam" [Lament for Two Unborn Poems] was published in 1965 as a response to Khrushchev's Kremlin speech attacking the arts in March 1963. It is, in Hope's words, "a counter-attack on those who would subject the artist to the demands of party programmes and Socialist-Realist prescriptions" (Hope, "Voznesensky's 'Lament"' 39). Hope reviews the Soviet commentary on Voznesensky's poem and concludes that it misses the point by attributing the poet's failure to write the two poems to laziness, when in fact it is really due to cowardice: "the poet has failed in a higher duty than that due to the Union of Writers or the Russian state" (Hope, "Voznesensky's 'Lament"' 46). This article engages in quite detailed textual analysis, pointing out Voznesensky's covert allusions to his contemporaries and to the current political situation, as well as examining Voznesenskii's humour and the linguistic mechanisms he uses in order to link together apparently disparate images. Unwillingness to compromise in the face of official criticism is also in part the subject of an unpublished general essay on Voznesensky, which again touches on his status as a follower of Pasternak, and on the importance of performance to Voznesensky's work. ${ }^{44}$

Hope was clearly attuned to the non-aesthetic, broadly political or historical component of many other Russian works, even though 
often he did not bring his ideas into final written form. In his unfinished essay on Pushkin's "Kapitanskaia dochka," for example, he notes Pushkin's implied criticism of Catherine the Great's handling of the Pugachev Rebellion of the 1770s and highlights the narrative strategies Pushkin employs to protect himself from possible charges of disloyalty to the tsarist regime. ${ }^{45}$ Hope also showed an interest in Pasternak's treatment of history in Doktor Zhivago. Hope was overall somewhat ambivalent towards the novel, writing: "I find myself rather confused about Dr Zhivago. I don't think it a great novel or even a very good novel, but I found that I was both excited and moved by reading it." 46 Hope appears to have been particularly struck by Pasternak's use of coincidence in the novel, although no detailed comments on this theme are extant. ${ }^{47}$ The relationship between historical cause and effect may well also have been the topic of Hope's proposed essay on Tolsoi's $W$ ar and Peace.

\section{V}

So far as it can be reconstructed, Hope's projected book of essays both affirms the importance for him of Russian literature, and recapitulates and extends motifs well known to readers of his verse and other critical writing: the centrality and persistence of the European tradition; the emphasis on poetic craftsmanship with due acknowledgement of the multiple sources of inspiration; the view of the poet as 'chosen' and as the guardian of cultural heritage. The Russian and Soviet context for this last point gives it a sharper edge, by extending the poet's role from a purely cultural to a moral, social and political plane which is rarely addressed in Hope's own poetry, but is nevertheless present in, for example, the cycle "Homage to Akhmatova." Quite apart from the intrinsic value of Hope's insights into the particular Russian authors which he examines, the proposed book, therefore, constitutes a significant metapoetic statement.

Why then did Hope not succeed in bringing his Russian project to completion? No doubt many factors were involved, not least the difficulty of finding a publisher in a period of contraction of scholarly book publishing. From the mid-1980s, glasnost and perestroika in the Soviet Union turned much of the public attention that might have been directed to Russian literary concerns towards more immediately pressing questions of world politics, and the book may have been less attractive to publishers for this reason. Moreover, if Hope's writing on Russian literature failed to attract a publisher for a general audience, it was not really suited to an 
academic readership either, being essentially the work of a poet rather than a scholar. Although when he started publishing on Russian themes in the 1960s Hope's ideas were certainly fresh and original, Russian literary studies enjoyed a massive explosion of interest in the 1960s and 1970s, with which, given his other duties and the large number of literary projects with which he was involved, Hope would have found it difficult to keep up. Certainly, his work was not situated within the mainstream of Anglophone Russian literary scholarship.

Some of Hope's ideas proved to have been already anticipated by other researchers. For example, his notion that Pushkin's Don Juan was based on elements of the author's biography was foreshadowed in an article published by Anna Akhmatova in 1947 (although Hope could only have become familiar with it on its republication in volume two of Akhmatova's complete works in 1968, the year after the appearance of his own article). ${ }^{48}$ Furthermore, Hope incorporated a good deal of his Russian material devoted to inspiration and to poetic creativity into the essays of The New Cratylus; on a poetic level this material is also reflected strongly both in "Homage to Akhmatova" and in Hope's tribute to Mandelstam, "In Memoriam: Osip Mandelstam, December 1938"49 (Wells). As perhaps the most original part of his writing on Russian literature was thus already in the public domain, there was less reason to publish the Russian essays as a whole, and less incentive to complete those that remained unfinished.

Nevertheless, Hope's project had a high level of internal coherence and it is clear that the resonances between the Russian essays and Hope's other writing are considerable. A study of them, however incomplete, confirms Hope as a writer at the centre of the European modernist tradition, an "Orphic" poet striving to preserve and to proselytise the value of the poetic word, and to include the Russian cultural world incontrovertibly in the foreground of his literary vision. Hope's available writing on Russian literature is incisive and compelling; it is only to be regretted that he did not bring the project to a conclusion.

\section{NOTES}

This paper draws extensively on Hope's papers at the National Library of Australia. I am grateful to Professor Geoffrey Hope for granting me permission to consult restricted parts of his father's archive and to the staff of the Manuscripts Reading Room of the NLA for their assistance. 
A.D. Hope, Orpheus (Sydney: Angus \& Robertson, 1991), 12.

Kevin Hart, A.D. Hope (Melbourne: Oxford University Press, 1992), 56-7.

3 Hope to Florence Hope, 25 April [1930?], NLA MS 5836/14/138.

4 Hope to Florence Hope, 14 January 1929, NLA MS 5836/14/138. See also A. D. Hope, Chance Encounters (Melbourne: Melbourne University Press, 1992), 76.

$5 \quad$ Directed by Martin Berge in 1928.

6 Hope to Florence Hope, 10 March [1930?], 3 March [1930?], NLA MS 5836/14/139.

7 Hope to Penelope Robinson, undated, but later annotated "early 1939" in Hope's hand, NLA MS 5836/636.

8 Notebook V, 1. 9, NLA MS 5836/99.

$9 \quad$ Notebook XI, 1. 108, NLA MS 5836/102.

10 A. D. Hope, The New Cratylus: Notes on the Craft of Poetry (Melbourne: Oxford University Press, 1979), 6.

11 A. D. Hope, "Anna Akhmatova's Secrets of the Craft," in Essays to Honour Nina Christesen: Founder of Russian Studies in Australia, ed. Judith Armstrong and Rae Slonek (Melbourne: Australian International Press \& Publications, 1979), 64.

12 Notebook XV, 11. 35-6, NLA MS 5836/104.

13 See Hope to Penelope Hope, 6 August 1946, NLA MS 5836/77/636. See also Judith Armstrong, The Christesen Romance (Melbourne: Melbourne University Press, 1996), 92.

14 "Notes for Akhmatova Lectures 1976," NLA MS 8536/290/260; “Mandelstam Lecture 1976," NLA MS 5863/29/262; "Pasternak: Dr Zhivago da stikhi [Dr Zhivago and poems]," NLA MS 5863/29/264; "Russian Odds and Ends," NLA MS 5863/74/613.

15 Notebook XIII, ll. -12, NLA MS 5836/103.

16 "Irina Andreyevna Fedosova," NLA MS 5863/29/254; "Karolina Pavlova," NLA MS 5863/28/247.

17 See Ann McCulloch, Dance of the Nomads: a Study of the Selected Notebooks of A. D. Hope (Canberra: Pandanus Books, 2005), 17-9.

18 Notebook XIII, 11. 89-90, NLA MS 5836/10/103.

19 Notebook XI, 11. 59-9, NLA MS 5836/10/102.

20 A. D. Hope, "Foreword," in David Campbell and Rosemary Dobson, Moscow Trefoil: Poems from the Russian of Anna Akhmatova and Osip Mandelstam (Canberra: Australian National University Press, 1975), xii.

21 Seven Russian Poets: Imitations by Rosemary Dobson and David Campbell (Brisbane: University of Queensland Press, 1979). On the notion of "adequateness" in verse translation and the nature of poetic meaning informing these imitations, see also Robert Dessaix, "The Adequate Metaphor: Differing Concepts in the Translation of Poetry," Melbourne Slavonic Studies 17 (1983): 21-40. 
22 A.D. Hope, "Anna Akhmatova: the Secrets of the Craft," Quadrant (Sept. 1977): 6-8.

23 David Wells, "A.D. Hope and the Poetics of Acmeism," Southerly, 68, 3 (2008): Long Paddock: http://www.brandl.com.au/ southerly\% 20longpaddock / 3-68/davidnwells.html

24 A. D. Hope, The Pack of Autolycus (Canberra: Australian National University Press, 1978). See note in A.D. Hope, "The Blind Swallow: Some Parleyings with Mandelstam," Melbourne Slavonic Studies, 9-10 (1975): 12; "Voznesensky's Lament for Two Unborn Poems," NLA MS 5836/29/257; “Andrey Voznesensky: Article for M. Slavonic Studies," NLA MS 5836/29/258; Joy W. Hooton, A. D. Hope (Melbourne: Oxford University Press, 1979), 97, 100.

25 Nina Christesen to Hope, 21 July 1982 \& Amanda Haight to Hope 26 July 1982, NLA MS 5836/74/613.

26 "Volume of Russian Essays," NLA MS 5836/74/613.

27 NLA MS 5836/29/256.

28 "Sadko and Other Essays on Russian Writers," NLA MS $5836 / 29 / 265$.

29 "Volume of Russian Essays," NLA MS 5836/74/613.

30 "Volume of Russian Essays"; "Nabokov," NLA MS 5863/29/263.

31 A. D. Hope, "The Blind Swallow"; "The Swallow and the Bee," NLA MS 5863/29/256; "Mandelstam's 'Tristia,"” NLA MS 5863/29/261; see Wells, "A. D. Hope and the Poetics of Acmeism."

32 Hope, "Anna Akhmatova: The Secrets of the Craft"; A. D. Hope, "Anna Akhmatova's Secrets of the Craft." See also "Akhmatova and the Muse," NLA MS 5863/73/606.

33 "Sadko," NLA MS 5863/29/263.

34 A. D. Hope, "Dostoevsky and Nietzsche," Melbourne Slavonic Studies 4 (1970): 38-45.

35 A.D. Hope, "Voznesensky's 'Lament for Two Unborn Poems,", Melbourne Slavonic Studies 7 (1972): 38-57.

36 A. D. Hope, "Pushkin's Don Juan," Melbourne Slavonic Studies 1 (1967): 1-10.

37 “Pushkin: The Captain's Daughter," NLA MS 5863/76/635.

38 "Notes on Pasternak's Imagery," NLA MS 5863/29/264; Notebook XI, 11. 21-3, NLS MS 5863/10/102 (“Giving things their names”).

39 "Radio Review of Andrew Field's Nabokov: His Life in Part, NLA MS 5863/29/263.

40 "Natalia Goncharova: a Case for the Defence," NLA MS 5836/29/263; Notebook X, ll. 128-36, NLA MS 5836/10/102; "Natalya Goncharova: a Case for the Defence," NLA MS 5836/74/618.

41 A. D. Hope, Collected Poems, 1930-1970 (Sydney: Angus \& Robertson, 1972), 237. 
42 A. D. Hope, Antechinus: Poems 1975-1980 (Sydney: Angus \& Robertson, 1981), 89.

43 A. D. Hope, "Safe Conduct," Helix 7-8 (1981): 156-64.

44 “General Essay on Voznesensky," NLA MS 5863/74/617.

45 “Pushkin:The Captain's Daughter,” NLA MS 5863/76/635.

46 "Lecture on Dr Zhivago," NLA MS 5863/264.

47 See "Lecture on Dr Zhivago"; Notebook VII, NLA MS 5863/100, l. 26; Notebook XII, 1. 43v., NLA MS 5863/103; Notebook XIX, 11. 134-6, NLA MS 5863/106.

48 Anna Akhmatova, Sochineniia, vol. 2, ed. G. P. Struve and B. A. Filippov (New York: Inter-Language Literary Associates, 1968), 25774.

49 A.D. Hope, A Late Picking (Sydney: Angus \& Robertson, 1975), 79_ 80. 